\title{
Hours and wages in the Depression: British engineering, 1926-1938
}

\author{
Robert A Hart \\ Department of Economics \\ University of Stirling \\ Stirling FK9 4LA \\ Scotland, UK \\ (e-mail: r.a.hart@stir.ac.uk)
}

First version: May 2000

This version: April 2001

\begin{abstract}
:
On their intensive margins, firms in the British engineering industry adjusted to the severe falls in demand during the 1930s Depression by cutting hours of work. This provided an important means of reducing labour input and marginal labour costs, through movements from overtime to short-time schedules. Nominal basic wage rates dropped relatively modestly while their real wage equivalents continued to rise throughout the trough years of the recession. This paper provides detailed labour market and empirical analysis of the hours and wage adjustment processes. Quantitative work is based on cell data from a panel of 28 local labour markets for the period 1926-38. The data dichotomise between skilled fitters and unskilled labourers and between time-rate and piece-rate workers.
\end{abstract}

\section{JEL Classification Numbers: E24, J31, N34}

Acknowledgements: The author is grateful to David Bell, David Blanchflower, Felix FitzRoy, Julia Darby, Olaf Hübler, Robert Margo (Associate Editor) and two referees as well as to seminar participants at the Universities of Hanover and Manchester for helpful comments on earlier drafts. Rosalind Hart and Elizabeth Roberts provided research assistance. The usual disclaimer applies. 


\section{Introduction}

During the Great Depression, British national unemployment rates reached a peak of 22 percent of the total insured workforce in 1933. It was not uncommon in the early years of the 1930s for local labour markets to experience rates exceeding 30 per cent. High unemployment itself suggests directly that firms responded to severe demand downturns by laying-off significant numbers of workers. But there were two other potentially important labour market response-mechanisms. The first was to reduce hourly wage rates. The second was to cut the length of the workweek. For many firms, shorter hours had the dual impact of reducing the size and the marginal cost of labour input. For the most important and strategic industry in the inter-war period, the engineering industry, this paper shows that hours adjustment was considerably more important than wage adjustment. It advances labour market reasons for this comparative observation and presents a detailed empirical investigation of the hours and wage adjustment processes.

The action of reducing wage rates in response to a recession carries clear advantages to the firm. It helps to maintain competitive prices in a declining market as well as avoiding some of the adjustment costs of layoffs. But it may also lead to offsetting losses, including declines in worker morale and efficiency. A further complication is that wage cutting may be subject to exogenously imposed constraints, such as national and regional level minimum wage agreements. An alternative strategy is to cut weekly hours. On the benefit side to the firm, reduced working time may involve unit cost reductions. These arise from two main sources. First, there may exist diminishing marginal productivity in daily and/or weekly hours. Second, cuts in hours may entail reduced average hourly wage rates as the proportion of overtime to total weekly hours declines. Given possible wage bargaining constraints, hours' 
adjustments may also offer a speedier adjustment mechanism. On the cost side, reduced hours are likely to be associated with spare capacity and inefficient use of plant. Further, as with wage rate cuts, reduced weekly hours involve a drop in takehome pay among workers.

At the intensive margin, the overwhelming response of engineering firms to the deepening recession was to reduce average working hours. ${ }^{1}$ By contrast, nominal wage rates displayed modest downward adjustments while real hourly wages generally rose. ${ }^{2}$ In fact, several of the key observations of British labour market performance in the 1930s find strong echoes in contemporary U.S. experience. Bernanke and Powell (1986) also find that real wages in U.S. manufacturing were countercyclical in the interwar period. These authors observed rising real wages between 1929 and 1937 against the background of extremely high unemployment rates. Moreover, they also find that variations in hours constituted a major adjustment mechanism, displaying a contribution to variation in total labour input that was almost on a par with that of employment. Further, Bernanke (1986) finds that hours provide a fairly rapid adjustment mechanism. Comparisons between the developments here and Bernanke's U.S. work are made in later sections.

Empirical work is based on a unique annual panel of 28 local labour markets in England and Scotland. For federated engineering firms within each market, the Engineering Employers' Federation (EEF) has constructed payroll-based data on

\footnotetext{
${ }^{1}$ Apart from the national agreement to set the standard workweek at 47 hours in 1919, employers experienced relatively weak constraints on their abilities to set weekly hours (overtime and short time).

${ }^{2}$ Dimsdale et al. (1989) provide an analysis and explanation of real wage growth during this period.
} 
working time and wages. ${ }^{3}$ The period of analysis is 1926 to 1938 . Statistics refer to

EEF federated firms. ${ }^{4}$ The study also incorporates unemployment rates that are constructed to match each local market (Hart and MacKay, 1975). There are two important dichotomies featured in the data set. First, it distinguishes between skilled fitters and unskilled labourers. Second, it differentiates between timeworkers and pieceworkers. $^{5}$ The latter group comprises a significant part of the total workforce in this industry. Over our entire sample, 57\% of fitters and 15\% of labourers were pieceworkers. $^{6}$

Background information - on the engineering industry in general and on EEF wages and hours in particular - is presented in Section 2. A labour market discussion of

${ }^{3}$ More details concerning the EEF and data coverage are provided in the Appendix.

${ }^{4}$ With some gaps, the EEF collected these statistics up to 1968. In 1964 and 1968, the timings of the EEF survey and the (then) Ministry of Labour's (MoL) broader engineering coverage coincided and we know from Hart and MacKay (1975) that, for the four groups of workers included here, the two sources produced very close earnings' estimates in these years. We also know from Knowles and Robertson (1951a) that there was a good correspondence between EEF and MoL data for both average earnings and average hours in 1947 and 1948. Between the 1940s and 1960s, the Federation represented between 2000 and 4500 engineering firms (on a rising trend) and between 800 thousand and 1.3 million manual workers. In the second-half of the 1920s and 1930s, the Federation represented between 2500 and 1800 firms (on a falling trend) as well as 600 thousand manual workers in the mid 1920s, falling to just under 400 thousand in 1931 and then rising to over 700 thousand by the late 1930s. [Marsh, (1965, p. 48) presents details.] While the sample coverage is large, it should be acknowledged that gaps between EEF and the MoL data are inevitable, especially at local labour market level. Strictly, the analysis here should be regarded as more representative of federated engineering firms than the industry as a whole.

${ }^{5}$ The total numbers of fitters and labourers by the two payments methods always exceeded 60,000 each year.

${ }^{6}$ The proportions of pieceworkers as a percentage of total workers in engineering grew considerably within these two groups in the first half of the century. In 1906, they comprised $29.8 \%$ of fitters and $8.6 \%$ of labourers with these pecentages increasing, respectively, to $60.8 \%$ and $22.6 \%$ by 1948 (Knowles and Robertson, 1951b). 
hours and wage adjustments during the Depression is carried out in Section 3. More formal developments concerning the derivations of hours' equations are set out in Section 4, with a critical emphasis on the distinction between time-rate and piece-rate workers. Section 5 outlines the specification of hours and wage functions. The former link closely to the theory in Section 4. The latter are based on Phillips curve and wage curve specifications in order to reflect the fact that wage bargaining occurred at a more aggregate level among federated firms. Estimates of hours and wage formulations are presented in Sections 6. Concluding comments are made in Section 7.

\section{Facts and figures}

Before concentrating on the two key variables of this paper, hours and wages, it is useful to describe briefly the composition, geographical location and performance of the British engineering industry before the Depression years. The industry embraced a great complexity of firms and products. It was predominantly concerned with the manufacture of metal products and the skills of its workforce were largely taken up with shaping, milling, machining and fitting (Marsh, 1965). Several sectors - such as mechanical, marine, instrument and electrical engineering - are clearly defined and recorded in the Standard Industrial Classification of the Census of Production.

Others define sub-sets of metal manufacture, vehicles and 'metal goods not elsewhere specified'. Outside of these sectors, the incidence of engineering jobs was far less well delineated. $^{7}$

\footnotetext{
${ }^{7}$ However, there is quite detailed information on the constituent engineering sectors
} of the EEF (see the Appendix). 
Geographically, several of the well-defined engineering sectors tended to cluster in distinct locations. ${ }^{8}$ Textile engineering predominated in Lancashire and the West Riding of Yorkshire, marine engineering on the NE Coast of England and on the Clyde in Scotland, motor and cycle manufacture in the Midlands and electrical engineering in London, the Midlands and Lancashire. In general terms, the South of England and the Midlands enjoyed a disproportionate share of newer and expanding engineering companies while the older contracting, or stagnating, industries concentrated more in the North of England and Scotland.

During the First World War, engineering employment increased more than any other occupation. Using two broad definitions of engineering, Pollard (1969) indicates that employment rose by between 4 and 6 percent from 1911 to 1921, with a workforce size of between 1.8 and 2.5 million workers in the latter year. In a somewhat longerterm perspective, however, the industry size as a whole had not greatly expanded. Engineering output in 1924 was only slightly higher than in 1907. However, this seeming long-term constancy disguised considerable rises and (offsetting) declines across engineering sectors. Economic historians typically emphasise the distinction between basic (or declining) sectors and the new growth sectors (e.g. Aldcroft, 1970). Mechanical and textile engineering featured among the former while electrical engineering and motor manufacture were among the latter. For example, from the Census of Production, we find that mechanical engineering's share of total manufacturing net output fell from 9.6 to 7.0 percent between 1907 and 1924 while electrical engineering doubled from 1.4 to 2.9 percent. Respective changes in

\footnotetext{
${ }^{8}$ Hill and Knowles (1956) provide the most detailed geographical breakdown of the industry for the year 1952. Two large sectors - light general and construction engineering - are spread relative evenly across markets.
} 
employment shares were roughly comparable. ${ }^{9}$ Punctuated by a contraction in 19256, engineering output grew strongly between 1921 and 1928 before the large declines of the Depression years, 1929-1932 (see, e.g. Aldcroft, 1970, Table 9). But even in this famous downturn, the engineering sectors' heterogeneity shone through. Thus, while mechanical engineering output declined by 36 percent, electrical engineering bucked the general trend (along with the food and utility industries) with a 5 percent increase. Timings of cyclical upswings and downswings were also erratic across 'old' and 'new' sectors.

I now turn to wages and hours, with particular reference to EEF experience and data.

The structure of wages in British engineering between the wars was subject to important elements of national agreements. Prior to the First World War, wages were negotiated locally and large variations in district rates evolved. With the advent of the National Wages Agreement in 1917, uniform national increases came into force. However, there was no prior cancellation of the district rates; the structure was frozen throughout the inter-war period. The national increases had the effect of gradually narrowing the district differentials (Knowles and Hill, 1954). ${ }^{10}$ The wage provisions

\footnotetext{
${ }^{9}$ Pollard (1965) suggests that the newer industries such as motor engineering and electrical engineering "were expanding rapidly and absorbing much capital and labour from the declining sectors". However, it is not easy to obtain systematic evidence in support of this view. A detailed quantitative attempt to measure the relative impacts on industrial output changes in British manufacturing (including engineering sectors) of inter-industry employment shifts and rates of technical improvement has been undertaken by von Tunzelmann (1982). The technology effect was found to be much more substantial than the shift effect. Where the latter did occur it owed much to labour displacement from the 'old staple' industries (defined to contain 13 industries, including textile machinery and marine engineering).

10 The overall composition of wages contains a further complication. During the First World War, a supplementary bonus was paid to compensate for the increased cost of living. While intended as a temporary payment, it continued for the whole of the interwar period and beyond ( and referred to as the National Bonus). Knowles and
} 
at national-level determined the minimum national time rates for fitters and labourers.

These minima then formed a point of reference for establishing district-level wage differentials for these and other occupations. ${ }^{11}$ This process was not uniform since some districts paid more than the national minima. ${ }^{12}$ Examinations of wage differentials between fitters and labourers have featured most prominently in the earlier literature and the work here also concentrates on these two occupations. ${ }^{13}$

Given the simple structure of wage schedules in engineering, it is possible to distinguish with a reasonable degree of precision between the hourly basic, or straight time, wage rate (which excludes overtime hours) and hourly wage earnings (including overtime). EEF data provide statistics on average weekly earnings (E) and average weekly hours (h), and so average hourly earnings are $\mathrm{e}=\mathrm{E} / \mathrm{h}$. Fortunately, the premium payments pertaining to overtime hours followed quite simple rules during this time period ${ }^{14}$. These allow for an estimate of the average hourly (basic) wage rate, $\mathrm{w}$, given by

Hill (1954, especially Table 1) provide a detailed analysis of the impact of the bonus on basic rates.

${ }^{11}$ See, especially, Marsh (1965, Chapter 6). The EEF reported on nine broad occupational categories. Apart from fitters and labourers, they included turners, patternmakers, moulders, boilermakers, sheet metal workers, coppersmiths, and 'other' classes.

12 There were three organisational tiers of industrial relations in engineering, which were works, district and national levels. There were about 50 District Committee areas covering clusters of engineering firms in defined geographical areas. Marsh (1965, pp. 22-26 and Appendix A2) provides detailed information for 1963 which serves as a reasonable reflection of earlier organisation.

${ }^{13}$ Detailed discussions of the earnings evolutions of, and differentials between, these two occupations can be found in Knowles and Robertson (1951a).

${ }^{14}$ Overtime was paid on a daily basis in the form a premium rate on all hours in excess of 47 standard, hours. Up to 1931, the premium was 1.5 on all overtime hours except on Sundays and public holidays (during which double-time applied). Between 


$$
\begin{array}{ll}
\mathrm{w}=e=\frac{\mathrm{E}}{\mathrm{h}} & \text { if } \mathrm{h} \leq 47 \\
\mathrm{w}=\frac{\mathrm{E}}{47+(\mathrm{h}-47) 1.5} & \text { if } \mathrm{h}>47
\end{array}
$$

where 47 is the length of the standard workweek that applied to all workers in the industry and 1.5 is the premium rate. ${ }^{15}$

It is also important to distinguish between timeworkers and pieceworkers given considerable proportions of engineering workers in each category. How were numbers of workers in these two groups distributed among firms? Hill and Knowles (1956) have undertaken a detailed analysis of the 1952 EEF returns of 3786 individual firms. They find that, in the case of fitters, 60 per cent of firms paid their workers exclusively on a timework basis, 17 per cent exclusively by piecework while less than a quarter used a mixture of the two payments systems. As with timeworkers, there

1931 and 1946, time-and-one-third was paid on the first two hours of overtime for non-Sunday/public holiday working and thereafter the same rates applied as before. Small differences between pieceworkers and timeworkers and other minor complications over calculating overtime earnings are enumerated in Knowles and Hill (1954, p.285 and Appendix B).

${ }^{15}$ This formula for w has been used by other authors (e.g. Braun, 1971) and by the Ministry of Labour. 
Figure 1: Hours, wages, prices and unemployment, 1926-1938
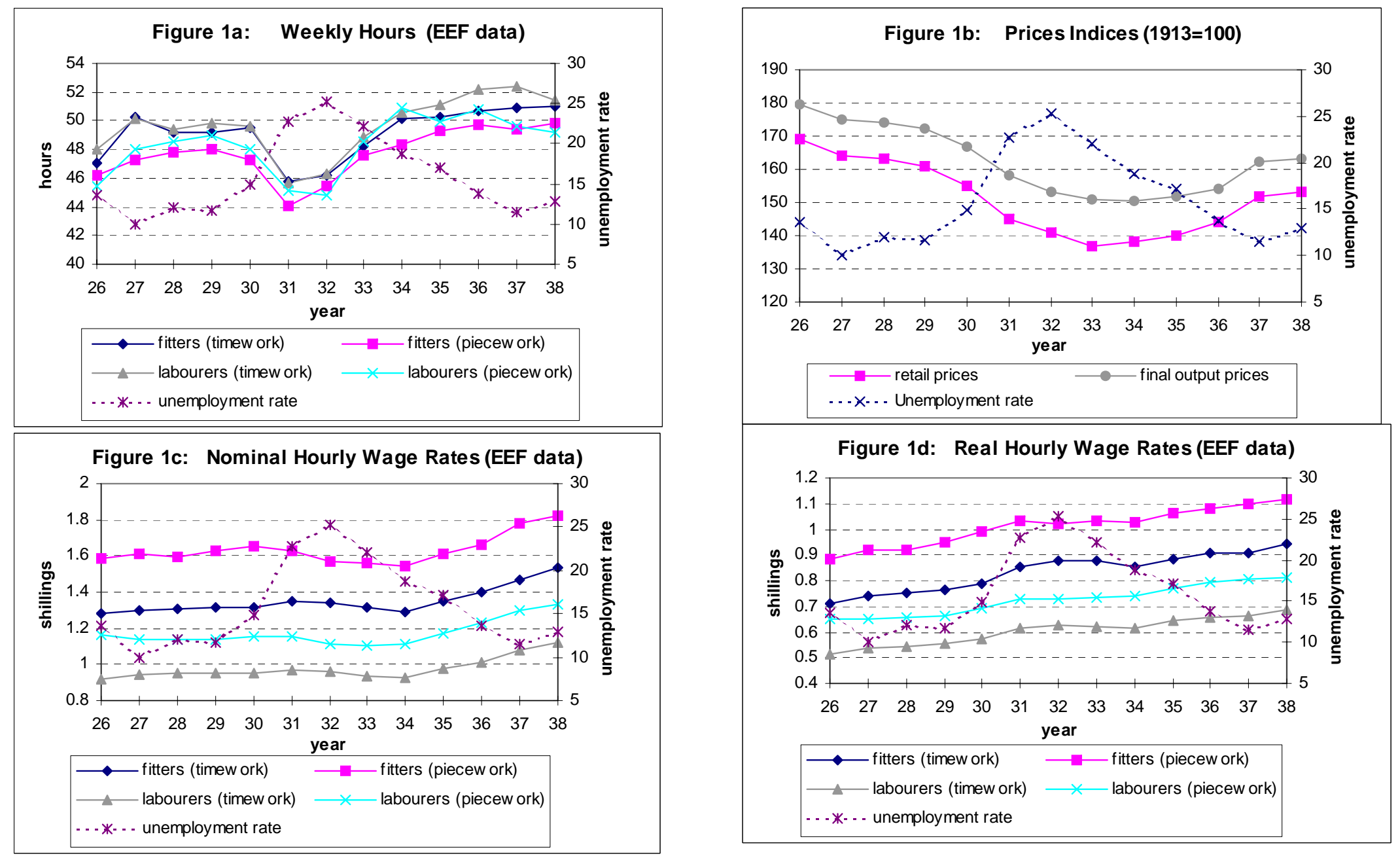
was an attempt in the inter-war period to impose some degree of national structure on piece-rates. The general practice was to fix piecework rates so that pieceworkers earned a given percentage more than the equivalent occupational basic time-rate. ${ }^{16}$ As discussed by Knowles and Hill (1954), the structure was by no means uniform, however.

Trends in hours, prices and wages against the background of unemployment rates are presented in Figure 1. The unemployment rates are the weighted averages of the 28 local labour markets used in this study. Hours and wages are also weighted averages of the EEF returns from these markets and they are presented separately for fitters and labourers by payments method. Retail and final output price indices are taken from Feinstein (1972), with retail prices based on the expenditures of working class families.

A strong negative association between industry-level hours and unemployment is immediately obvious from Figure 1a. Between 1929 to their peak in 1932, unemployment rates more than doubled, from 11.7 per cent to 25.3 per cent. In 1929, weekly hours of timeworking fitters averaged 49.2. These fell to a trough of 45.8 hours in 1931 - i.e. a 7 per cent reduction in 2 years - and then recovered slightly to 46.2 in 1932. Recalling that the standard workweek was 47 hours, short time was worked on average in engineering in these last two years. By 1931, about one-quarter of labour markets - mainly in Scotland and the North of England - experienced short time working which averaged more than 3 hours below weekly standard hours (see

${ }^{16}$ The differences were set at a minimum of 33.33 per cent between 1914 and 1931 and 35 per cent between 1931 and 1943. The percentage applied to the basic rate only; it did not include, for example, the National Bonus. 
also Table 1). Note that the hours of timeworking fitters and labourers correspond closely throughout most of the period. These groups worked longer hours than pieceworking fitters but were much closer to those of pieceworking labourers, especially in the second half of the period. Knowles and Robertson (1951a) show that pieceworkers' hours were generally shorter than those of timeworkers for other occupations in the industry. In general, however, differences in hours among the four groups included here were modest, with closely corresponding cyclical hours' movements.

What are the observed cyclical movements in nominal and real wages? The deflation of both retail and final output prices commenced in 1921 and prices fell to their trough values in 1934. During the study period, as shown in Figure 1b, final output prices fell by 16.2 per cent. The hourly wage rate data follow the construction of equation (1); that is, they exclude overtime hours. Figure 1c shows the changes in nominal hourly wage rates. Taking (the representative) example of timeworking fitters, nominal wages reached a peak of 1.35 shillings per hour in 1931 and fell to a trough of 1.29 shillings in 1934, a reduction of 4.5 per cent. The wages of pieceworking fitters and labourers exceeded those of their timeworking equivalents throughout the entire period. When wages are deflated by the final output price index ${ }^{17}$, real wage rates rose throughout the period with the exception of 1934 when three of the four employment groups experience very modest reductions.

\footnotetext{
${ }^{17}$ Thereby reflecting our firm-level labour demand approach adopted later.
} 
Figure 2 provides more disaggregate details on nominal wages and hours of timeworking fitters in a sample of 4 of the 28 labour markets. ${ }^{18}$ The wage data in Figure 2, showing trends in e and w, are set against each market's unemployment rate. The first two markets, London and the West Midlands - fared relatively well during the Depression. Their unemployment rates peaked at 16.9 and 19.7 percent, respectively. Interestingly, except for one year in the case of the West Midlands, average hourly earnings, e, always exceeded the hourly wage rate, w, in these two markets. In other words, average overtime was positive over the entire period. In sharp contrast, the northern labour markets of Oldham and Rochdale experienced respective unemployment peaks of 41.5 and 34.7 percent. Moreover, these markets averaged short time working (i.e. under 47 weekly hours) for significant numbers of years. Accordingly, e and w coincided during these periods. It is also noticeable that nominal wages rose for most of the period. Nominal wage reductions were experienced around 1933 and 1934 in these and other markets, that is two or three years after unemployment peaked. Unsurprisingly, given the aggregate results in Figure 1, the real wage paths shown in Figure 3, display virtually persistent upward trends. The real wage falls in 1933/4 are very slight in relation to the wage growth over the full period.

\footnotetext{
${ }^{18}$ Hart and MacKay (1975) provide decompositions of hours and wages for combined time-rate/piece-rate fitters and labourers in all 28 markets.
} 
Figure2: Nominal wage rates, nominal wage earnings and unemployment in selected labour markets (fitters, time-rates)
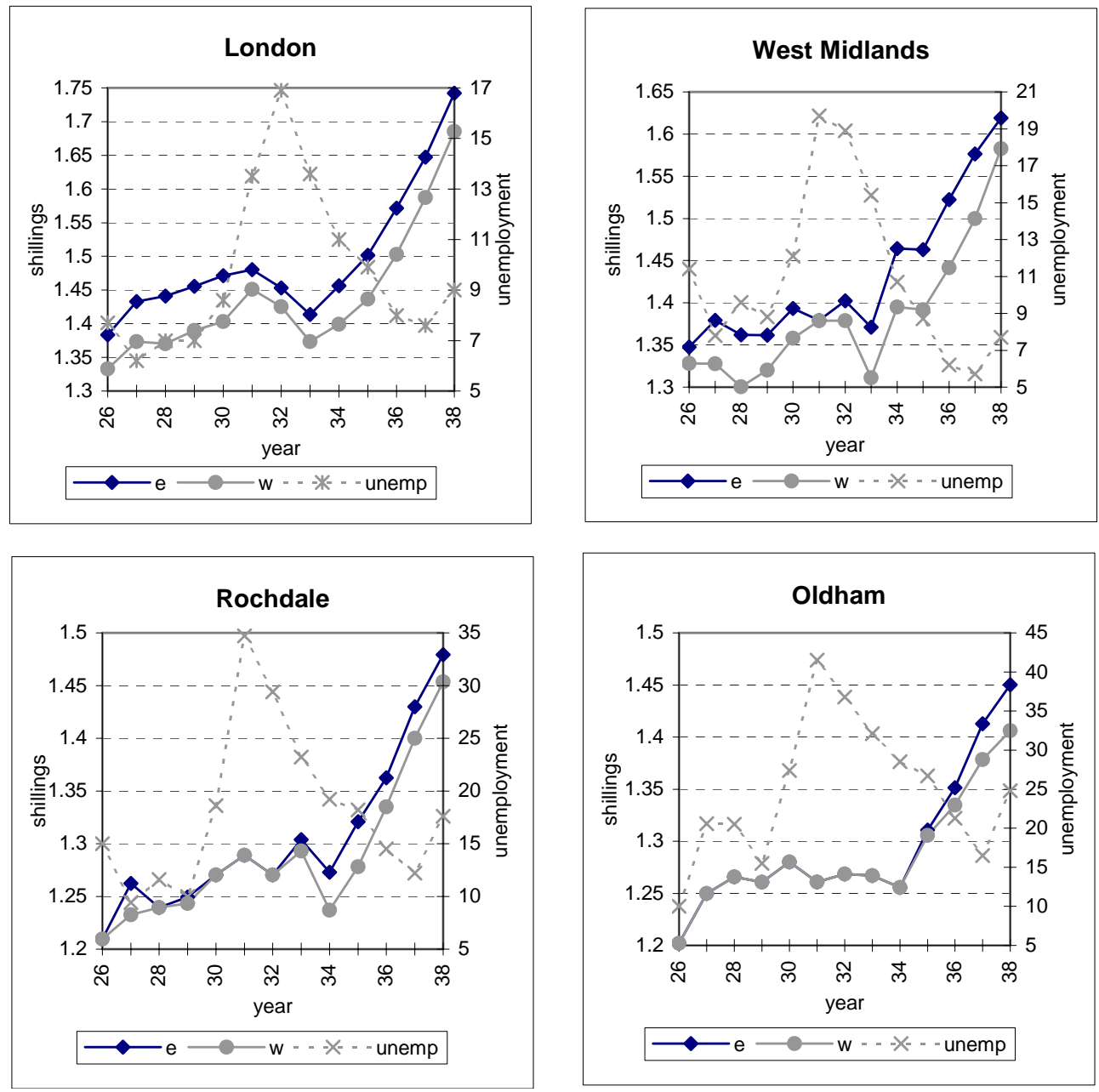

Associated weekly hours' movements are shown in Figure 4. As a marker, the aggregate unemployment rates shown in Figure 1 are also included. All four markets experienced hours' reductions, albeit shallower in the more resilient London and West Midlands markets. Note that hours reduce steeply in 1929 and 1930, thereby displaying a more contemporaneous response to the deepening recession. This contrasts sharply with the long lag in nominal wage responsiveness. 
Figure 3: Real wage rates, real wage earnings and unemployment in selected Labour markets (fitters, time-rates)
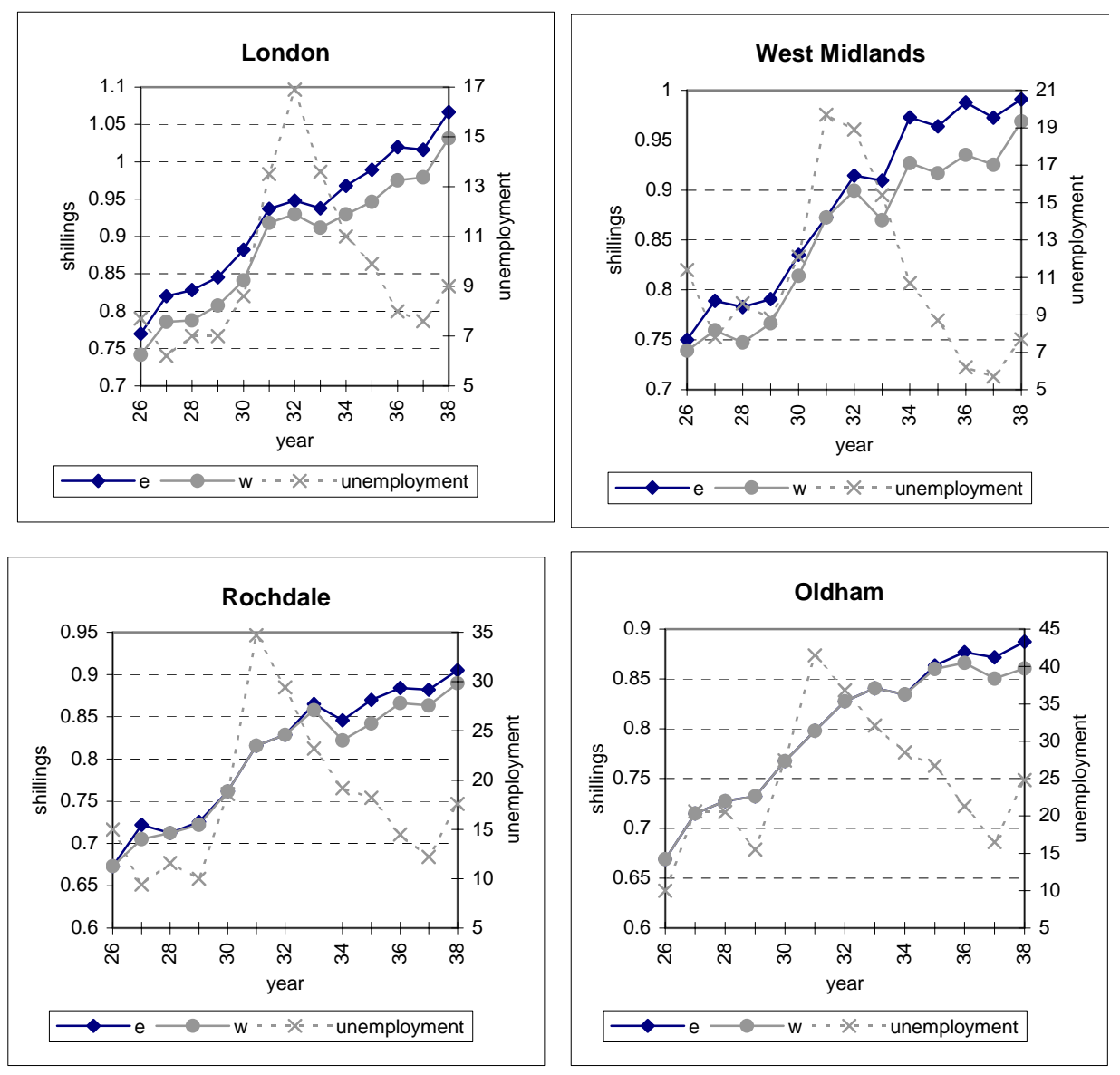

Figure 4: Weekly hours in selected labour markets (fitters, time-rates)

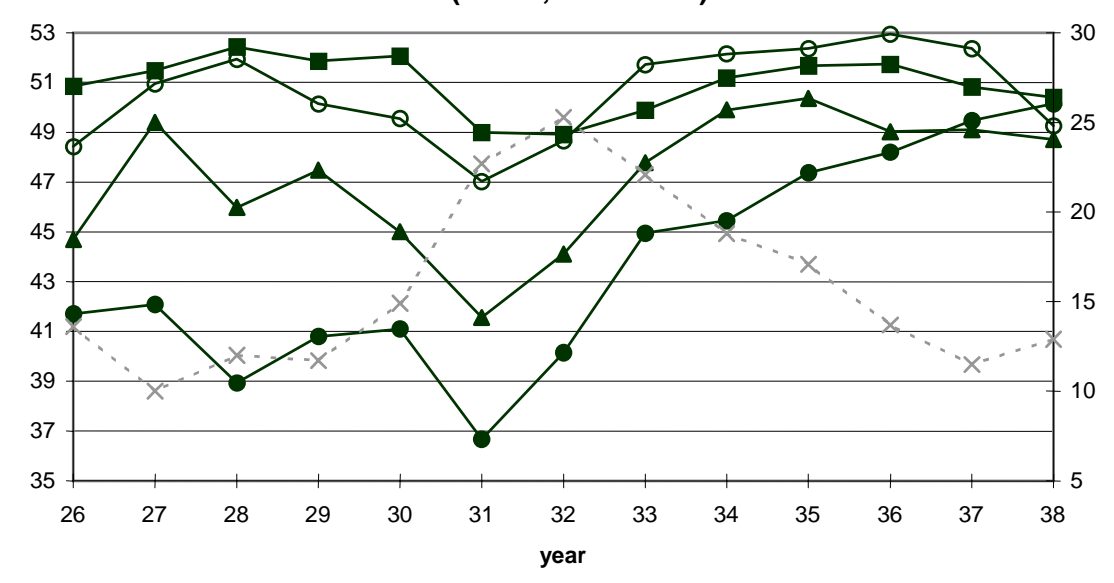

$\longrightarrow$ London $\longrightarrow$ - West Midlands $\longrightarrow$ Rochdale $\longrightarrow$ Oldham $-\cdot-x$ - - unemplyment 
Figures 1- 4 suggest the quantitative importance of hours' cutbacks as a means of reducing labour input. Such hours' responses also serve to reduce hourly compensation by narrowing, or eliminating, the gap between e and w. As examples, this latter effect is noticeable in London and the West Midlands in Figures 3 where the real e - w gaps narrow appreciably during the early 1930s. By contrast, in a labour market like Oldham where short time working was the norm, this influence on the hourly rate of compensation was not so important.

\section{Hours and wage adjustments across local labour markets}

Three important questions arise from the foregoing descriptive background. First, why did hours adjust but not wage rates in the Depression? Second, why were there large variations in hours' adjustments across local labour markets? Third, how did changes in hours affect marginal labour costs across markets? One key consideration helps to cast light on these issues. This is the fact that there was an uneven geographical distribution of the major engineering sectors.

Detailed breakdowns by engineering sector and geographical location are not available but we can obtain useful insights in respect of two highly contrasting sectors, textile and motor vehicle engineering. In the inter-war period, the latter sector was considerably more economically resilient than the former. ${ }^{19}$ Engineering firms in the motor vehicle industry were heavily concentrated in the West Midlands and Coventry while textile engineering was dominant in Lancashire and Yorkshire (including the towns of Bolton, Blackburn, Halifax, Oldham and Rochdale). Table 1

\footnotetext{
${ }^{19}$ For example, real output in the textile industry in 1937 was the same as in 1913 while the vehicle industry grew five-fold between these dates - see Feinstein (1972), Table 115. Further, engineering firms in the motor vehicle sector suffered less recessionary impact - at least in terms of sectoral unemployment rates - than textiles (see Garside, 1990, Table 5).
} 
shows that in 1928 and 1931 textile engineering experienced short time hours that were considerably above the average for engineering as a whole, while vehicle construction was below. ${ }^{20}$ Clearly, the textile towns' experience of short time working in these years - shown in the top part of Table 1 - was far more marked than in the West Midlands and Coventry, the centres of motor vehicle engineering.

It is reasonably safe to infer that markets with a preponderance of firms in older engineering sectors exhibited greater degrees of short time working than markets with a larger share of newer sectors. Now, consider labour turnover in this context. Assume that inter-market labour mobility in specific engineering occupations was relatively low. ${ }^{21}$ Labour turnover involves fixed costs related to hiring and training. ${ }^{22}$ At any given time, employers in the markets with declining industries would face significantly lower turnover-related costs because local job opportunities were scarce. The probability of finding alternative employment in such markets would have approached zero towards the recessionary troughs. In this event, the employer faced a lower risk of losing skilled and experienced workers with the introduction of short time working and its accompanying reduction in weekly earnings. One advantage of

${ }^{20}$ Aircraft engineering is also chiefly located in the Coventry and the West Midlands and it too experienced relative little short time working (see Table 1). Note also that marine engineering (located in the Scottish, N.E. Coast and Barrow areas), did experienced a relatively high loss in hours due to short-time working in 1931 compared to an extremely low loss in 1928.

${ }^{21}$ The greater the diversity of industrial mix between markets, the less inter-market mobility might be expected because of occupational and skill mismatches. In fact, there is evidence that the influx of insured labour into the Midlands from Lancashire was relatively modest at this time (see Thomas, 1938).

${ }^{22}$ Such costs would be expected to be especially important in the case of skilled fitters included in the data set here. 
Table 1 Short-time and overtime working in engineering, 1928 and 1931

\begin{tabular}{|c|c|c|c|c|}
\hline \multirow{3}{*}{\begin{tabular}{|l|} 
\\
Labour market
\end{tabular}} & \multicolumn{4}{|c|}{ Weekly hours minus $47^{1}$} \\
\hline & \multicolumn{2}{|c|}{1928} & \multicolumn{2}{|c|}{1931} \\
\hline & Fitters & Labourers & Fitters & Labourers \\
\hline Aberdeen & -1.4 & 2.8 & -1.8 & -0.6 \\
\hline Barrow & -2.2 & 0.2 & 0.1 & -0.2 \\
\hline Bedfordshire & -5.9 & 2.7 & 0.9 & 0.4 \\
\hline Blackburn & -1.0 & -0.6 & -2.2 & -1.6 \\
\hline Bolton & 1.7 & 0.4 & -4.4 & -5.0 \\
\hline Burnley & -2.8 & -4.2 & -6.0 & -6.1 \\
\hline Burton $^{2}$ & -1.8 & 0.9 & 12.4 & 5.5 \\
\hline Coventry & 3.6 & 5.6 & -1.2 & 0.3 \\
\hline Derby & 0.5 & 1.4 & 1.2 & -2.0 \\
\hline Dundee & 0.0 & 1.2 & -3.8 & -6.7 \\
\hline Halifax & -0.2 & 0.0 & -1.9 & -2.9 \\
\hline Hull & 0.3 & 2.0 & -4.5 & -4.1 \\
\hline Leicester & 2.2 & 3.5 & -1.5 & -0.6 \\
\hline Lincoln & 0.9 & 1.0 & -2.3 & 0.1 \\
\hline Liverpool & 4.1 & 3.6 & -2.1 & -0.8 \\
\hline London Area & 5.4 & 7.5 & 2.0 & 2.9 \\
\hline Manchester & 4.0 & 3.7 & -1.8 & -0.4 \\
\hline N.E.Coast & 2.8 & 2.1 & -0.1 & -0.6 \\
\hline Nottingham & 4.2 & 1.1 & -2.3 & -1.2 \\
\hline Oldham & -8.1 & -16.0 & -10.3 & -14.3 \\
\hline Preston & 1.4 & 5.7 & 1.4 & -0.6 \\
\hline Rochdale & -1.0 & -0.1 & -5.4 & -8.3 \\
\hline St.Helens & 1.1 & 4.3 & 1.7 & -1.0 \\
\hline Scottish & 1.3 & 2.4 & -0.5 & -1.2 \\
\hline Sheffield & 4.7 & 4.3 & -0.4 & -2.8 \\
\hline West Midlands & 4.9 & 3.6 & 0.0 & -1.1 \\
\hline \multirow[t]{2}{*}{ Wigan } & -1.7 & -2.2 & 0.1 & -2.2 \\
\hline & \multicolumn{4}{|c|}{ Average number of hours lost through short time per head of all workers } \\
\hline Engineering sector & & & & \\
\hline Textile & & & & \\
\hline Marine & & & & \\
\hline Aircraft & (les & $0.05)$ & & \\
\hline Motor vehicles & & & & \\
\hline - larger firms ${ }^{5}$ & & & & \\
\hline - smaller firms & & & & \\
\hline All engineering & & & & \\
\hline \multicolumn{5}{|c|}{$\begin{array}{l}\text { Notes: 1. Data refer to fitters and labourers on time rates and are taken from the EEF returns. The } \\
\text { standard workweek was } 47 \text { hours. Therefore, a negative number indicates the average } \\
\text { weekly short time working while positive numbers show average weekly overtime. } \\
\text { 2. The outlying figures for Burton in } 1931 \text { are almost certainly due to very small samples of } \\
\text { timeworking fitters and labourers in that year. } \\
\text { 3. Data obtained from Ministry of Labour Gazette (London, HMSO) for } 1929 \text { (p.401) and } \\
\text { refer to a sample of all firms. } \\
\text { 4. Data obtained from Ministry of Labour Gazette (London, HMSO) for } 1933 \text { (p.10) and refer } \\
\text { to a sample of all firms with } 10 \text { employees or more. } \\
\text { 5. Firms with } 25 \text { employees or more. }\end{array}$} \\
\hline
\end{tabular}


short time working is that it reduces labour input while avoiding the costs of hiring and training when product demand increases at some future date. By contrast, the probability of finding alternative employment is higher in markets dominated by expanding industries. If firms in these markets were to contemplate significant cuts in hours they would run greater risks of losing their best workers to competing enterprises, ceteris paribus. In essence, this is the story of the incidence of short time working that is more formally advanced and tested in subsequent sections.

Where significant short time working is feasible, it provides a mechanism for reducing not only labour input but also marginal employment costs. Note in Table 1 that the majority of labour markets in 1928 averaged positive overtime. By 1931 this picture had been transformed with nearly every market averaging weekly hours at or, in most cases, significantly below the 47- hour standard workweek. Since overtime is remunerated at a premium rate, a change in the proportion of overtime to weekly hours causes average hourly earnings to change even if hourly rates of pay remain constant. In other words, reductions in overtime hours would have given many engineering firms degrees of freedom to cut marginal costs in the face of demand downturns irrespective of whether or not their ability to change wage rates was constrained by national and district agreements. Note also that where overtime was relatively high prior to the Depression - such as in Coventry and the West Midlands then this cost adjustment mechanism would have provided a greater buffer against short-time working and layoffs.

But what about employers' ability to reduce basic wage rates? The complicating factor here was that, while firms had discretion over setting basic rates and other supplementary payments, minimum basic hourly rates of pay for fitters and labourers 
were negotiated for the entire industry at national level. As shown in Hart and MacKay (1975, Table 2), minimum nominal wage rates for fitters and labourers remained constant between 1929 and 1932, the trough years of the Depression, despite significant product price reductions (see Figure 1b). For firms paying wages at or near prescribed minima, real labour costs were forced upwards. Added to these nationally agreed wage rates, firms were required to pay a prescribed bonus (the National Bonus) that effectively added to basic rates. This centralised process ignored the differential impact of the Depression across local markets and so failed to provide wage rate adjustments that were in line with relative local economic experience. In the depths of the Depression, laid down national rates would almost certainly have prevented low paying firms from adequately reducing hourly rates. ${ }^{23}$ Therefore, this would have served to increase their propensity to have recourse to layoffs or short workweeks. Such constraints would be expected to have been particularly severe in northern labour markets with strong clusters of traditional and relatively declining engineering firms.

\footnotetext{
${ }^{23}$ Individual firm-level data are not available. However, Hart and MacKay (1975, Table 2) provide national estimates that point to the likelihood that many firms would find it difficult to carry out basic wage rate reductions when the Recession was at it deepest. Taking the example of fitters on time work in 1932, nationally agreed pay for a full basic workweek was 58 shillings, consisting of a 46 shillings basic pay and 12 shillings National Bonus. Actual average weekly fitters' earnings in 1932 were 62 shillings and 2 pence and so the earnings gap above the minimum weekly pay was 4 shillings and 2 pence. Therefore, on average, the earnings gap was a modest $6 / 7 \%$ of average total weekly pay. (Actually, as explained in Hart and MacKay, this gap is an overestimate of the 'true' gap.) Without much doubt, many firms were paying weekly wages at or near the nationally laid-down minima. For these firms there would be little scope to adjust rates adequately to meet demand downturns.
} 
This discussion provides three important pointers to the necessary structure of the empirical analysis of hours and wage adjustments.

(a) It is important to measure carefully the extent to which changes in hours of work helped to effect labour input adjustment to drastically changing demand conditions during the Depression.

(b) It is necessary to study movements of basic hourly wage rates in relation to changing demand patterns in order to gain insights into whether adjustment responses may have been impaired by such features as national and district rate setting.

(c) It is valuable to compare hourly wage earnings responses to those of basic wage rates in order to assess the contribution of overtime hours' fluctuations as a means of altering the marginal price of labour services.

\section{Hours of work by payment method under cost minimisation}

The modelling approach adopted here is based on the literature on the demand for workers and hours (see Hart, 1987 and Hamermesh, 1993). The firm is assumed to minimise costs subject to a production constraint. In the light of the earlier discussion, the hourly wage rate is treated as being set outside the workplace of an individual firm, at national and district levels. I approximate this process by wage curve and Phillips curve specifications that disaggregate to the level of the local labour market. The firm can influence hourly earnings through its hours' decisions. Fixed employment costs include a quit function and this permits my first innovation in respect of the standard workers-hours model, that is it allows me to integrate unemployment into the labour demand functions. For simplicity in this latter respect, I assume relatively low costs of intra- local labour market mobility while inter-market mobility is ruled out. My second innovation is to develop hours demand functions 
separately for timeworkers and pieceworkers. In the piece-rate specification, simultaneous wage-hours determination is an issue. The firm is treated as if all its employees are either timeworkers or pieceworkers. ${ }^{24}$ Capital stock is assumed fixed and workers are homogeneous. Without serious implications for the analysis, no differentiation is made between labour skills. (Although different skills are introduced into the empirical analysis via the two occupational groups.)

I do not accommodate household supply decisions on hours' and earnings' outcomes. This contrasts with Bernanke (1986) whose work on U.S. manufacturing (referred to as the primary sector) in the Depression embraces the dichotomy between workers and hours within a demand and supply model framework. The demand side involves a firm maximising profit, with costs incorporating the workforce payroll and nonlabour inputs. The supply side combines (a) an individual earnings function that rises convexly in hours (to reflect the individual's willingness to supply more working hours) as well as in reservation utility and (b) the primary sector's participation rate which rises in the utility offered in that sector. Labour supply (demand) increases (decreases) with the level of utility available in the primary sector. Equilibrium between demand and supply is established at the point where the reservation utility of the marginal worker is just enough to produce indifference between working in the primary and secondary (alternative) sectors. An important facet of Bernanke's story is that a decision to reduce hours of work by the firm, due to a fall in industrial demand, is constrained by the need to consider workers' preferences and reservation utilities.

\footnotetext{
${ }^{24}$ It has already been noted that the evidence reasonably supports this firm-level separation of payments' method. Lazear (1986) carries out a detailed comparative analysis of time-rate and piece-rate working. For a recent analysis of the coexistence of piece rates and time rates see Baland et al. (1999). Seiler (1984) presents an illuminating analysis of sources of variation in pay for timeworkers and pieceworkers.
} 
This produces the possibility that a particularly severe cut in hours may not be accompanied by an equivalent reduction in earnings. Accordingly, hourly earnings may rise when demand falls.

In Bernanke's work, hourly wage earnings are endogenously determined by the demand and supply equilibrium conditions. By contrast, in my approach the basic hourly wage is given and the firm manipulates hourly earnings through changes in hours demand. While Bernanke deals only in terms of hourly earnings, it is important in my analysis to differentiate between hourly wages and hourly earnings. Both models involve the optimal size of the workforce. However, unlike Bernanke, data constraints preclude me from estimating worker-demand functions. ${ }^{25}$ An offsetting advantage is that my data allow a far more detailed micro-level analysis; this allows me to eliminate the fixed effect influences of highly heterogeneous local labour markets.

\section{A timeworker firm}

Remuneration of each worker consists of a wage rate $\mathrm{w}_{\mathrm{T}}$ for $\mathrm{h}_{\mathrm{T}}$ per-period hours where $\mathrm{T}$ denotes a timeworker. Total variable cost is given by

$$
\mathrm{W}=\mathrm{w}_{\mathrm{T}} \mathrm{h}_{\mathrm{T}} \mathrm{N}
$$

where $\mathrm{N}$ is the size of the workforce.

The workforce also incurs fixed (or hours-independent) labour costs, given by

$$
\mathrm{Z}=(\mathrm{z}+\mathrm{tq}) \mathrm{N}
$$

\footnotetext{
${ }^{25}$ The labour market data are based on sample returns and we do not know the full employment numbers and so, in contrast to average hours, the stock dimension of production cannot be modelled.
} 
where $\mathrm{Z}$ is total fixed cost, $\mathrm{z}$ is (exogenous) non-human capital fixed cost, $\mathrm{t}$ is training cost and $\mathrm{q}$ is the quit rate. Training standards are assumed to be laid down at industry level and so, together with occupational homogeneity, training cost is treated as an exogenously determined constant. ${ }^{26}$ The quit rate is assumed to depend on (i) the firm's $\mathrm{w}_{\mathrm{T}}$ relative to the rate in other firms in the local market, $\mathrm{w}_{\mathrm{T}}{ }^{*}$ and (ii) the unemployment rate which represents the (inverse of the) probability of finding alternative employment in the market (see Schlicht, 1978; Salop, 1979; Hoel and Vale, 1986). Thus

$$
\mathrm{q}=\mathrm{q}(\mathrm{r}, \mathrm{u}) \text { where } \mathrm{r}=\mathrm{w}_{\mathrm{T}} / \mathrm{w}_{\mathrm{T}} *
$$

with $\mathrm{q}_{\mathrm{r}}<0, \mathrm{q}_{\mathrm{rr}}>0, \mathrm{q}_{\mathrm{u}}<0, \mathrm{q}_{\mathrm{ur}}>0$. Low intra-market information and mobility costs together with important elements of national and district elements of wage setting are assumed to ensure that $\mathrm{r}=1$ (i.e. $\mathrm{w}_{\mathrm{T}}=\mathrm{w}_{\mathrm{T}}{ }^{*}$ ). ${ }^{27}$ Therefore, the adopted special case of (4a) is given by

$$
\mathrm{q}=\mathrm{q}(1, \mathrm{u})
$$

Setting output price to unity, the Lagrangian function, L, for the firm's cost minimising problem is expressed

$$
\min \mathrm{L}\left(\mathrm{N}, \mathrm{h}_{\mathrm{T}}, \lambda\right)=\mathrm{Z}+\mathrm{W}+\lambda\left[\mathrm{Q}-\mathrm{F}\left(\mathrm{N}, \mathrm{h}_{\mathrm{T}}\right)\right]
$$

\footnotetext{
${ }^{26}$ In general, the menu of skills required to qualify as a fitter were generally understood throughout the industry although formalisation of training standards was more of an immediate post-war phenomenon (Marsh, 1965, pp. 170-5).

27 Arguably, weekly hours should also be included in equation (4a). For example, short time working may serve to make a given job less attractive. However, it is reasonable to assume that when unemployment is relatively high, the probability of finding an alternative local job at significantly increased hours is low enough to be discounted.
} 
where $Q$ is the firm's output, and $\lambda$ is a Lagrangian multiplier. It is assumed that $F_{i}>$ $0, \mathrm{~F}_{\mathrm{ii}}<0$ and $\mathrm{F}_{\mathrm{ij}}>0\left(\mathrm{i}=\mathrm{N}, \mathrm{h}_{\mathrm{T}}\right)$. From the first-order conditions, we obtain

$$
\frac{\mathrm{w}_{\mathrm{T}} \mathrm{N} *}{\mathrm{z}+\mathrm{tq}+\mathrm{w}_{\mathrm{T}} \mathrm{h}_{\mathrm{T}}^{*}}=\frac{\partial \mathrm{F} / \partial \mathrm{h}_{\mathrm{T}}}{\partial \mathrm{F} / \partial \mathrm{N}}
$$

where $\mathrm{N}^{*}$ and $\mathrm{h}_{\mathrm{T}}^{*}$ denote equilibrium values of the decision variables. Thus, the firm equates the ratio of marginal costs on the intensive (hours) and extensive (employment) margins to their respective marginal products. This model produces the equilibrium hours demand function

$$
\mathrm{h}_{\mathrm{T}}^{*}=\mathrm{h}_{\mathrm{T}}^{*}\left(\mathrm{w}_{\mathrm{T}}, \mathrm{z}, \mathrm{u}, \mathrm{Q}\right) .
$$

Totally differentiating the first order conditions and solving the $\mathrm{h}$ (and $\mathrm{N}$ ) variables establishes in (7) that $\mathrm{h}_{\mathrm{T} 1}^{*}<0, \mathrm{~h}_{\mathrm{T} 2}^{*}>0, \mathrm{~h}_{\mathrm{T} 3}^{*}<0, \mathrm{~h}_{\mathrm{T} 4}^{*}>0$. The first three conditions derive from the fact that a rise in hours-independent relative to variable costs induces hours-worker substitution. Following Ehrenberg (1971), it is noted that $\partial \mathrm{h}_{\mathrm{T}}^{*} / \partial \mathrm{Q}=0$ in (7) if there is an underlying homothetic (e.g. Cobb Douglas) production technology. This latter outcome is taken advantage of in the subsequent hours' estimating equations.

The variable of particular interest to this study is the rate of unemployment. Its role in equation (7) stems from the result that rises in fixed labour costs cause hours-worker substitution in the cost minimising firm. As unemployment increases, the quit rate reduces due to falls in alternative employment opportunities. Accordingly, fixed costs associated with labour turnover are reduced. Ceteris paribus, starting from an equilibrium position, the cost minimising firm reacts to falls in fixed to total labour costs by reducing the variable labour input, hours of work. 
A pieceworker firm $^{28}$

Remuneration of pieceworkers is performance-related. With fixed capital, the firm can attempt to control per-period output or performance by changing (i) average piece-rate hours $\left(\mathrm{h}_{\mathrm{P}}\right)$, and (ii) work intensity per hour $(\theta) .{ }^{29}$ Let piecework performance be indexed by $\Phi$ and so $\Phi=\Phi\left(\mathrm{h}_{\mathrm{P}}, \theta\right)$. It is assumed that $\Phi_{\mathrm{h}_{\mathrm{p}}}, \Phi_{\theta}>0$ and $\Phi_{\mathrm{h}_{\mathrm{p}} \mathrm{h}_{\mathrm{p}}}, \Phi_{\theta \theta}<0$ with the second derivatives capturing the influences of, respectively, worker fatigue and organisational/ technological constraints. Let the piece-rate be given by $\pi$ and so the total variable cost $(\mathrm{P})$ is given by

$$
\mathrm{P}=\left[\pi \Phi\left(\mathrm{h}_{\mathrm{P}}, \theta\right)\right] \mathrm{N}
$$

As for pieceworkers' fixed costs, it is assumed that (3) and (4b) apply. ${ }^{30}$

The new cost minimising problem is

$$
\min \mathrm{L}\left(\mathrm{N}, \mathrm{h}_{\mathrm{P}}, \theta, \lambda\right)=\mathrm{Z}+\mathrm{P}+\lambda\left[\mathrm{Q}-\mathrm{G}\left(\mathrm{N}, \mathrm{h}_{\mathrm{P}}, \theta\right)\right]
$$

where $G_{i}>0, G_{i i}<0$ and $G_{i j}>0\left(i=N, h_{P}, \theta\right)$. First-order conditions give $\mathrm{z}+\mathrm{tq}+\pi \Phi-\lambda \frac{\partial \mathrm{G}}{\partial \mathrm{N}}=0 ; \pi \frac{\partial \Phi}{\partial \mathrm{h}_{\mathrm{P}}} \mathrm{N}-\lambda \frac{\partial \mathrm{G}}{\partial \mathrm{h}_{\mathrm{p}}}=0 ; \pi \frac{\partial \Phi}{\partial \theta} \mathrm{N}-\lambda \frac{\partial \mathrm{G}}{\partial \theta}=0 ; \mathrm{Q}=\mathrm{G}$

\footnotetext{
${ }^{28}$ This sub-section is based on Pencavel (1977) who analyses an equivalent supplyside problem.

${ }^{29}$ The ability of the firm to vary work intensity would be expected to be very systemsoriented. For example, it is more likely to be feasible within a firm that adopts lineproduction techniques and perhaps less likely in a firm involved in small-batch production.

${ }^{30}$ The equivalent quit function to (4a) for pieceworkers is $q\left(\pi / \pi^{*}, u\right)$ where $\pi^{*}$ is the piece-rate in other firms. In like manner to time-rates it is assumed that $\pi=\pi^{*}$ given low mobility and other transaction costs within local labour markets. I ignore the possibility of switching between time-rate and piece-rate work.
} 
We obtain the outcome that the firm equates the ratio of the marginal costs of hours and work intensity with their respective ratio of marginal returns, that is

$$
\frac{\partial \Phi / \partial \mathrm{h}_{\mathrm{P}}}{\partial \Phi / \partial \theta}=\frac{\partial \mathrm{G} / \partial \mathrm{h}_{\mathrm{P}}}{\partial \mathrm{G} / \partial \theta}
$$

The piecework equilibrium hours demand function is given by

$$
\mathrm{h}_{\mathrm{P}}^{*}=\mathrm{h}_{\mathrm{P}}^{*}(\pi, \mathrm{z}, \mathrm{u}, \mathrm{Q}) .
$$

On totally differentiating the first-order conditions and solving for the endogenous variables, it is established that all the partials now have ambiguous signs. The intuition is as follows. In the timeworker model it is found that $\partial \mathrm{h}_{\mathrm{T}}^{*} / \partial \mathrm{w}_{\mathrm{T}}<0$. A rise in variable cost reduces the cost of employment on the extensive relative to the intensive margin and thereby encourages the firm to substitute $\mathrm{N}^{*}$ for $\mathrm{h}_{\mathrm{T}}^{*} \cdot{ }^{31} \mathrm{~A}$ comparable result, i.e. $\partial \mathrm{h}_{\mathrm{P}}^{*} / \partial \pi<0$, occurs in the pieceworker model iff $\partial \Phi / \partial \theta=0$. In this event, the wage-rate and the piece-rate clearly play strictly comparable roles. However, if $\partial \Phi / \partial \theta>0$, the sign of $\partial \mathrm{h}_{\mathrm{P}}^{*} / \partial \pi$ is indeterminate. A ceteris paribus rise in the piece-rate not only alters the relative prices of intensive margin inputs, $\mathrm{h}_{\mathrm{P}}$ and $\theta$, relative to extensive margin input $(\mathrm{N})$ but also of intensive margin inputs relative to one another. Knowledge of the degree of complementarity or substitutability between $h_{P}$ and $\theta$ is required before unambiguous causation is established.

From an empirical viewpoint, the hours' demand functions (7) and (11) are not compatible since workers are compensated by unit of time in (7) and by unit of output in (11). Instead, for pieceworkers, I adopt the hours' function

\footnotetext{
${ }^{31}$ This occurs because fixed costs are also incurred with respect to employment while per-hour costs are purely variable.
} 


$$
\mathrm{h}_{\mathrm{P}}^{*}=\mathrm{h}_{\mathrm{P}}^{*}\left(w_{\mathrm{p}}, \mathrm{z}, \mathrm{u}, \mathrm{Q}\right)
$$

where $\mathrm{w}_{\mathrm{p}}$ is the hourly rate of pay of pieceworkers. In terms of (8), let $\mathrm{p}=\mathrm{P} / \mathrm{N}$ be the average variable cost. Then, we have $\mathrm{w}_{\mathrm{P}}=\mathrm{p} / \mathrm{h}_{\mathrm{P}}=\pi \Phi / \mathrm{h}_{\mathrm{P}}$. So, $\mathrm{w}_{\mathrm{P}}$ is functionally related to $\pi, h_{p}$ and $\theta .^{32}$ Therefore, estimation of hours' demand, i.e. equation (12), should accommodate two features. First, some attempt to capture the influence of $\theta$ is necessary. Second, estimation must take account of simultaneity between $h_{p}$ and $w_{p}$.

\section{Hours and wage specifications}

Data consist of 28 local labour markets observed over 13 years and are dichotomised between fitters and labourers and between timeworkers and pieceworkers. This gives a maximum of 1456 cell-observations although in practice only 1188 are available for estimation purposes (see the Appendix). Pooling the cross sections in this way allows for tests of differences among the employment groups. Unemployment rates are available for each labour market in each year. The EEF produce hourly wages for timeworkers and pieceworkers separately.

Hours' estimation is based on the demand equations (7) and (12). The estimating equation is designed to capture both shift- and slope-effects of piecework relative to timework compensation systems. The underlying production function is assumed to be homothetic, in which case $\partial \mathrm{h} / \partial \mathrm{Q}=0$ would hold. The hours equation also includes labour market and time series dummies. The cross-section dummies allow us to control, at least as a first approximation, for the influence of work intensity $(\theta)$ in the pieceworker hours equation (12). As earlier noted, differences in work intensity

\footnotetext{
${ }^{32}$ Following Pencavel (1977), if we take the Cobb-Douglas form of the X-function, that is $\mathrm{w}_{\mathrm{P}}=\pi \mathrm{dh}_{\mathrm{P}}{ }_{\mathrm{d}_{1}} \theta^{\mathrm{d}_{2}} / \mathrm{h}_{\mathrm{P}}$, we obtain $\ln \mathrm{W}_{\mathrm{P}}=$ constant $+\ln \pi+\left(\mathrm{d}_{1}-1\right) \operatorname{lnh} \mathrm{h}_{\mathrm{P}}+\mathrm{d}_{2} \ln \theta$.
} 
would be expected to relate to type of production system and method. Different labour markets are associated with different sectors of engineering and so probably act as a reasonable proxy for $\theta$. As discussed below, the dummies also control for social welfare costs (payroll taxes) incurred by the firm.

Let I and S be dichotomous variables that denote, respectively, the operation of an incentive pay scheme (pieceworking) and a skilled worker (fitter). Denote $\ln \mathrm{h}_{\mathrm{it}}$ as the $\log$ of average hours of workers in local labour market $\mathrm{i}$ at time t. Let $\mathrm{X}_{\mathrm{jit}}$ denote the $\mathrm{j}^{\text {th }}$ determinant - also expressed as a market average - of $\ln \mathrm{h}_{\mathrm{it}}$. The basic estimating hours' equation is given by

$$
\ln \mathrm{h}_{\mathrm{it}}=\mathrm{a}_{0} \mathrm{I}_{\mathrm{it}}+\mathrm{a}_{1} \mathrm{~S}_{\mathrm{it}}+\sum_{\mathrm{j}} \mathrm{b}_{\mathrm{j}} \mathrm{X}_{\mathrm{jit}}+\mathrm{r}_{\mathrm{m}}+\mathrm{f}_{\mathrm{t}}+\varepsilon_{i t}
$$

where $r_{m}$ and $f_{t}$ are unrestricted labour market and time intercepts, $\varepsilon_{i t}$ is an error term and where a and $\mathrm{b}$ are parameters to be estimated. Included in $\mathrm{X}$ are: (i) the log of the unemployment rate $\left(\ln \mathrm{u}_{\mathrm{it}}\right)$; (ii) the log of the straight-time hourly wage (ln $\left.\mathrm{w}_{\mathrm{it}}\right)$. The hours' equations also contain hours'-independent fixed costs, z. It is possible to obtain measures of fixed costs consisting of employers' per worker contributions to unemployment and health insurance (Chapman, 1952, Table 91). However, payroll tax funding of this social welfare coverage was such that costs per-worker were constant across all workers in a given year. Therefore, they are fully captured by the dummies. $^{33}$

\footnotetext{
${ }^{33}$ Because they are fixed costs, higher health and unemployment benefit payments by firms would lead to an hours - worker substitution, ceteris paribus. The time dummies capture this potential effect on the demand for hours. Garside (1990) also draws attention to a feature of the unemployment insurance regulations in the interwar period that may have encouraged short time working. This was the "rule whereby any three days of unemployment occurring within a period of six consecutive days could be considered as continuous and therefore irrelevant so far as eligibility for benefit was concerned encouraged employers...to arrange lay offs to satisfy the
} 
In order to gain some insight into the speed of hours' adjustment - and despite econometric problems associated with dynamic panel specifications (e.g. Hsiao, 1986) - an extended version of (13) was estimated that included the lagged dependent variable. These results are also included in the following section.

Hours' estimation was extended to allow for I- and S- worker slope differences as well as to allow for which $\mathrm{I} \times \mathrm{S}$ interaction dummies. ${ }^{34}$ In the event, slope and interaction terms proved to be insignificant (see the discussion in the following section) and so attention is concentrated on equation (13). Estimation of (13) is carried out using weighted two- stage least squares, with w treated as an endogenous variable (see Notes to Table 1).

On the wages' side, I specify simple wage-unemployment relationships in order to capture the national and local labour market wage setting. An obvious augmented wage formulation, since it too is based on regional cell means, is the wage curve specification of Blanchflower and Oswald (1994). This is given by

$$
\operatorname{lnw}_{\mathrm{it}}=\alpha_{0} \mathrm{I}_{\mathrm{it}}+\alpha_{1} \mathrm{~S}_{\mathrm{it}}+\beta \ln \mathrm{u}_{\mathrm{it}}+\gamma \ln w_{i t-1}+\mathrm{r}_{\mathrm{m}}+\mathrm{f}_{t}+v_{i t}
$$

where $\mathrm{w}$ is constructed as in (1), $\alpha, \beta, \gamma$ and $\delta$ are parameters to be estimated, and $v$ is an error term. ${ }^{35}$ Blanchflower and Oswald argue that a finding of $\gamma=0$ is supportive

waiting period requirement" (Garside, p 24). This effect is not captured by the analysis here.

34 The full specification is given by:

$\ln \mathrm{h}_{\mathrm{it}}=\mathrm{a}_{0} \mathrm{I}_{\mathrm{it}}+\mathrm{a}_{1} \mathrm{~S}_{\mathrm{it}}+\mathrm{a}_{2} \mathrm{I}_{\mathrm{it}} \mathrm{S}_{\mathrm{it}}+\sum_{\mathrm{j}} \mathrm{b}_{1 \mathrm{j}} \mathrm{X}_{\mathrm{jit}}+\sum_{\mathrm{j}} \mathrm{b}_{2 \mathrm{j}} \mathrm{I}_{\mathrm{it}} \mathrm{X}_{\mathrm{jit}}+\sum_{\mathrm{j}} \mathrm{b}_{3 \mathrm{j}} \mathrm{S}_{\mathrm{it}} \mathrm{X}_{\mathrm{jit}}+\sum_{\mathrm{j}} \mathrm{b}_{4 \mathrm{j}} \mathrm{I}_{\mathrm{it}} \mathrm{S}_{\mathrm{it}} \mathrm{X}_{\mathrm{jit}}+\mathrm{r}_{\mathrm{m}}+\mathrm{f}_{\mathrm{t}}+\varepsilon_{\mathrm{it}}$.

35 There are no market price deflators and so exact measurement of real wages is precluded. However, following standard practice in this type of model, the cross 
of a wage curve specification while $\gamma=1$ supports the Phillips curve. ${ }^{36}$ With an eye on problems associated with the inclusion of a lagged dependent variable in panels, Card (1995) and Card and Hyslop (1996) suggest that first-differencing equations like (14) provides a test of the wage curve versus the Phillips curve. In terms of (14), this produces

$$
\Delta \ln \mathrm{w}_{\mathrm{ijt}}=\beta_{1} \operatorname{lnu}_{\mathrm{it}}+\beta_{2} \operatorname{lnu}_{\mathrm{it}-1}+\mathrm{g}_{\mathrm{t}}+\Delta v_{i t-1}
$$

where $g_{t}$ is the re-normalised time effect. If in (15) $\beta_{1}$ is found to be significant and $\beta_{2}$ insignificant then this provides empirical support for the Phillips curve. Alternatively, estimates of $\beta_{1}$ and $\beta_{2}$ reveal equal sized parameters with opposite signs then the wage curve is supported.

Wages in equations (13), (14) and (15) are, through (1), adjusted to remove the influence of overtime working; in other words, they are basic hourly wage rates. I argue in Section 3, however, that is also important to estimate hourly earnings equations. This enables us to judge the extent to which changes in overtime working as opposed to changes in basic wage rates - accounted for labour cost adjustments.

sectional (fixed effects) and year dummies can reasonably be expected to act to control for market price differences and movements. Note that, given the diverse concentrations of engineering sectors across labour markets, it is important to control for cross-sectional variations in the deflators.

${ }^{36}$ See, especially, Table 5 of the Blanchflower and Oswald U.K. study based on 11 UK standard regions between 1973-90. Apart from region and time dummies, these authors additionally control for occupation, industry, qualifications, marital status and several other variables. However, their main controls are not essential in this study. Occupation is far more rigorously defined here, consisting of two quite homogenous blue-collar groups. There is only one industry. (Although, there would be an advantage in a more detailed delineation of types of engineering outside those captured by the regional dummies.) Nor is it important to control for pre-work education in the case of fitters and labourers. Added to this, the labour markets here are much better defined than standard geographical regions; in fact, the great majority define travel-to-work areas. 
This issue is raised by Card (1995), and explored in some detail by Black and FitzRoy (1999), in relation to estimating the wage curve. The topic is explored below by reestimating equations (14) and (15) and replacing w with e.

\section{Hours and wage estimates}

Estimates of the hours' equation (13) are presented in Table 2. The results in column (i) match closely to the theory presented in Section 3. In line with the cost minimisation models, hours' elasticities indicate significantly negative wage and unemployment responses. The estimated unemployment elasticity of hours is -0.03 , so that a doubling of local labour market unemployment is associated with a 3 per cent reduction in hours. In fact, unemployment more than doubled in magnitude between 1929 and 1932 (see Figure 1) and would have accounted for, at least, an average work time reduction of 90 minutes per week. Also consistent with the theory, the hours-wage elasticities are significantly negative. Since wages rose significantly in most labour markets between 1928 and 1932 (see, for example, Figure 2), this also contributed to the decline in working hours. The S- dummy indicates that fitters worked longer weekly hours than labourers. Contrary to the impression of the aggregate graph in Figure 1a, the I- dummy suggests that pieceworkers worked longer hours than timeworkers. It should be added that, in general, hours' differences among the four groups are small.

While we must be tentative about the results in column (ii) of Table 2, the estimated coefficient on lagged hours indicates that hours adjust relatively speedily to their desired levels, with around 70 per cent of adjustment achieved in the current year. Comparing columns (i) and (ii), the unemployment result remains very robust while 
the coefficient on the lagged wage halves in size - though remaining significantly

negative - when lagged hours are added.

Table 2 Hours' estimates (Weighted 2SLS: dependent variable: $\ln \mathbf{h}_{t}$ )

\begin{tabular}{|c|c|c|}
\hline \multirow{3}{*}{ Unemployment $\left(\ln \mathbf{u}_{t}\right)$} & (i) & (ii) \\
\hline & -0.029 & -0.026 \\
\hline & $(0.008)$ & $(0.008)$ \\
\hline \multirow[t]{2}{*}{ Wage rate $\left(\ln w_{t}\right)$} & -0.369 & -0.181 \\
\hline & $(0.038)$ & $(0.071)$ \\
\hline \multirow[t]{2}{*}{ Incentive pay dummy (I) } & 0.023 & 0.004 \\
\hline & $(0.007)$ & $(0.011)$ \\
\hline \multirow[t]{2}{*}{ Skill dummy (S) } & 0.115 & 0.055 \\
\hline & $(0.013)$ & $(0.023)$ \\
\hline Lagged hours $\left(h_{t-1}\right)$ & - & $\begin{array}{c}0.334 \\
(0.065)\end{array}$ \\
\hline \multirow[t]{2}{*}{ Dummy 1} & 0.505 & 0.411 \\
\hline & $(0.018)$ & $(0.034)$ \\
\hline Dummy 2 & $\begin{array}{c}0.212 \\
(0.013)\end{array}$ & $\begin{array}{c}0.159 \\
(0.021)\end{array}$ \\
\hline $\begin{array}{l}\text { Labour market and time } \\
\text { dummies }\end{array}$ & Yes & Yes \\
\hline \multicolumn{3}{|c|}{$\begin{array}{l}\text { Notes: No. of observations = 1188. Figures in parentheses are heteroscedastic consistent } \\
\text { standard errors (White, 1980). The instrument for } \ln _{\mathrm{t}} \text { is obtained by regressing this variable } \\
\text { on deviations from the mean wage (by occupation group) for each year, unemployment, lagged } \\
\text { unemployment as well as occupation, regional and time dummies and using the resulting fitted } \\
\text { wage. Weights are the number of employees recorded by the Engineering Employers' } \\
\text { Federation in each occupation and pay group in each local labour market. } \\
\text { Dummy } 1 \text { applies to Barrow in } 1927 \text { where exceptionally high hours and wages resulted from } \\
\text { work on the trials of H.M.S Cumberland during a large part of October, the month of data } \\
\text { collection. } \\
\text { Dummy } 2 \text { applies to Barrow in } 1930 \text { were a number of naval trials accounted for unusually } \\
\text { high hours and earnings per worker. }\end{array}$} \\
\hline
\end{tabular}

Accommodating slope influences of I and S on the explanatory variables in the hours' equations - as well as allowing for interactions between I and S - added nothing to the results shown in Table 2. It is indicated in Section 2 that, in important respects, the determination of piece-rates in engineering was formulaically linked to time-rates. The results with respect to the incentive-pay slope dummies suggest that, to all intents 
and purposes, firms did not differentiate their hours' responses as between the two rates. Nor did they apparently differentiate in their responses in relation to fitters and labourers. This might well indicate large degrees of interrelated work activities between these two occupational groups.

Table 3 Hourly wage/earnings - unemployment relationships (Weighted OLS)

\begin{tabular}{|c|c|c|c|c|}
\hline Independent Variables & $\begin{array}{c}\Delta \ln \mathbf{w}_{\mathbf{t}} \\
\text { (i) }\end{array}$ & $\begin{array}{c}\Delta \ln \mathbf{e}_{\mathbf{t}} \\
\text { (ii) }\end{array}$ & $\begin{array}{l}\ln w_{t} \\
\text { (iii) }\end{array}$ & $\begin{array}{r}\ln \mathbf{e}_{\mathbf{t}} \\
\text { (iv) }\end{array}$ \\
\hline Unemployment $\left(\ln u_{t}\right)$ & $\begin{array}{l}-0.009 \\
(0.008)\end{array}$ & $\begin{array}{l}-0.021 \\
(0.006)\end{array}$ & $\begin{array}{l}-0.009 \\
(0.009)\end{array}$ & $\begin{array}{l}-0.020 \\
(0.006)\end{array}$ \\
\hline Lagged unemployment $\left(\ln \mathbf{u}_{t-1}\right)$ & $\begin{array}{c}0.006 \\
(0.007)\end{array}$ & $\begin{array}{c}0.022 \\
(0.006)\end{array}$ & $\begin{array}{c}0.003 \\
(0.010)\end{array}$ & $\begin{array}{c}0.024 \\
(0.009)\end{array}$ \\
\hline Lagged wage $\left(\ln w_{t-1}\right.$ or $\left.\ln e_{t-1}\right)$ & - & - & $\begin{array}{c}0.690 \\
(0.039)\end{array}$ & $\begin{array}{r}0.681 \\
(0.048\end{array}$ \\
\hline Incentive pay dummy (I) & - & - & $\begin{array}{c}0.050 \\
(0.007)\end{array}$ & $\begin{array}{r}0.046 \\
(0.008)\end{array}$ \\
\hline Skill dummy (S) & - & - & $\begin{array}{c}0.104 \\
(0.013)\end{array}$ & $\begin{array}{r}0.106 \\
(0.016)\end{array}$ \\
\hline Dummy 1 & $\begin{array}{c}0.464 \\
(0.010)\end{array}$ & $\begin{array}{l}0.567 \\
(0.090)\end{array}$ & $\begin{array}{c}0.453 \\
(0.008)\end{array}$ & $\begin{array}{r}0.560 \\
(0.008)\end{array}$ \\
\hline Dummy 2 & $\begin{array}{c}0.276 \\
(0.106)\end{array}$ & $\begin{array}{c}0.319 \\
(0.098)\end{array}$ & $\begin{array}{c}0.276 \\
(0.006)\end{array}$ & $\begin{array}{c}0.324 \\
(0.006)\end{array}$ \\
\hline $\begin{array}{l}\text { Labour market and time } \\
\text { dummies }\end{array}$ & - & - & Yes & Yes \\
\hline Time dummies & Yes & Yes & - & - \\
\hline \multicolumn{5}{|c|}{$\begin{array}{l}\text { Notes: No. of observations = 1188. Figures in parenthesis are standard errors and are } \\
\text { heteroscedastic consistent. Hourly wages (w) exclude overtime and follow the } \\
\text { construction of equation (1). Hourly earnings (e) include overtime. Weights are the } \\
\text { number of employees recorded by the Engineering Employers' Federation in each } \\
\text { occupation and pay group in each local labour market. }\end{array}$} \\
\hline
\end{tabular}

Wage equation results are shown in Table 3. Columns (i) and (ii) contain, respectively, the wage rate and earnings rate regressions equivalent to equation (15).

Results in the former case are weak with neither a wage curve nor a Phillips curve receiving any support. The equivalent earnings results in column (ii) transform the picture. Unemployment now plays a 'traditional' role, with the results strongly 
supporting a wage curve specification. Basic hourly wage rates in the two occupational groups were unresponsive to demand fluctuations (as proxied by unemployment) in the inter-war period. Hourly wage earnings, by contrast, exhibit significant positive associations with demand. It is safe to infer, therefore, that earnings adjustment in general was achieved by reducing the proportion of overtime premium payments within total pay rather than by cutting basic wage rates.

Columns (iii) and (iv) in Table 3 present results to the wage curve specification in equation (14) for wages and earnings, respectively. The shift dummies indicate that pieceworkers enjoyed higher wage rates than timeworkers, and fitters higher wages than labourers. The lagged wage coefficient suggests slow adjustment relative to the adjustment speeds obtained in the hours' equations. ${ }^{37}$ The w-u elasticities are insignificant with, again, no evidence supporting either a Phillips or wage curve for this period. By contrast, the earnings results in column (iv) corroborate the equivalent $\Delta$ e regression results in column (ii).

\section{Conclusions}

Significant cuts in working time among British engineering firms in the early 1930s were undertaken in the face of rising unemployment and rising wage rates. Hours' changes allowed firms to reduce labour input while offsetting upward pressures on labour costs as the recession deepened. The cost reductions occurred because most labour markets moved from workweeks in which average hours exceeded standard

\footnotetext{
${ }^{37}$ These results contrast to those of Blanchflower and Oswald (1994) who do not find significant autoregression in their equivalent wage equations, based on cell means. They are more in line with the US findings of Blanchard and Katz (1997), although these authors find an even more sluggish wage adjustment process.
} 
hours to those in which short-time working was the norm. A related advantage of hours' cutbacks was that, due to the prevalence of short-time working, levels of labour utilisation were relatively costlessly reversible as and when cyclical upturns took place. Somewhat more cautiously, there are also indications that hours provided a relatively speedy form of adjustment.

By contrast, basic wage-rate changes did not adapt to the prevailing economic climate, as revealed by the wage-unemployment estimates in Table $3 .^{38}$ The wage determination process in British engineering was almost certainly an important factor in this respect. In the first place, the process was relatively cumbersome. Minimum time-rates of fitters and labourers - both timeworkers and pieceworkers - were set by national-level industry agreements and then consolidated at district level. Second, national and district level negotiations were made against a background of a wide heterogeneity of local labour market economic climates and industrial activities. As discussed in Section 3 and elsewhere, some labour markets were dominated by declining engineering sectors and others by growing sectors, even during the depth of

${ }^{38}$ It is interesting to note that the absence of a Phillips wage-unemployment relationship was not confined to engineering, however. Phillips' original scatter diagram of British annual nominal wage changes and unemployment between 1923 and 1957 (Phillips, 1958) - reproduced and analysed in detail by Lipsey (1960) reveals a set of points between 1923 and 1939 that under no stretch of the imagination support a negative wage-unemployment relationship. Lipsey is especially interested in the (centralised first-difference) rates of change of wages $(\dot{W})$ and of unemployment $(\dot{U})$. He compares the periods $1923-39$ and 1947-57 with the period1862-1913 and finds that the regression coefficient on $\dot{U}$ changes signs. He goes on to observe that "on the average experience of the post-1922 period, other things being equal, times of falling unemployment were associated with lower $\dot{\mathrm{W}}$ 's than were times of rising unemployment". 
the Depression. The wide variations of market structure and performance would have made it extremely difficult to reach aggregate-level agreements over reductions in nominal rates that matched, let alone exceeded, the accompanying price deflation. In effect, real wage rates were allowed to adapt very gradually with the main cyclical buffers provided by labour utilisation rates within firms themselves. This point is underlined in the Table 3 results. When hourly earnings replace hourly rates, standard Phillips curve/wage curve relationships are observed. This is due principally to procyclical hours, not wage rate, responses.

These interpretations of events are highly dependent on the centralised wage setting structure within British engineering in the inter-war years. Bernanke (1986) offers a different explanation for countercyclical manufacturing hourly earnings in the U.S. during this period. In his analysis, workers' preferences and the availability of outside opportunities influenced firms' payment decisions. As in Britain, U.S. firms cut weekly hours in the face of reduced demand. While workers like shorter hours they dislike the accompanying drop in wage earnings. This leisure-consumption trade-off will change according to levels of work and pay. When work was particularly scarce and pay low in the Depression years, workers would value consumption highly relative to leisure. As a result, firms may have felt constrained from cutting weekly earnings as deeply as hours. This could have led to hourly earnings rises even when demand and weekly hours were falling. In Bernanke's story, workers' utility constraints may have led to the occurrences of acyclical or countercyclical hourly earnings. In mine, centralised wage bargaining against the backdrop of divergent market requirements helped to produce hourly wage rate inertia. In both, hours' flexibility in the face of changing demand conditions was of fundamental importance. 


\section{Appendix}

\section{The EEF and local labour market data}

The EEF acted as a trade union on behalf of the management of its federated firms

(Marsh, 1965, Ch. 3). It represented the whole range of activities of the engineering industry with firms organised into 30 manufacturing sub-sectors. These included aircraft, agricultural machinery, commercial vehicles, construction engineering, foundries, general engineering, machine tools, marine engineering, motor cars and cycles (see Hill and Knowles, 1954, Appendix A, and Marsh, 1965, Appendix B). During the period of study, the EEF represented on average 2000 firms and 800,000 workers nation-wide. The title, EEF is used for convenience. The Federation was formed in 1896 and the title EEF adopted in 1899. Federated membership grew significantly up until the early 1920s, with a particular boost in 1919 when it amalgamated with the National Employers' Federation. This led to an eventual change of name to the Engineering and Allied Employers' National Federation in 1924.

With less disaggregation than incorporated here, these data were originally described in Hart and MacKay (1975) and a detailed breakdown of each local labour market is given in Marsh (1965, Appendix B). The EEF hours and wage data refer to a particular pay week, which falls in the month of October for the years 1926-8 and 1932-7, March for 1929-31 and July for 1938. The twenty-eight labour markets are listed in Table 1.

The potential sample size in the regressions is $1456(=28$ markets $\times 13$ periods $\times 4$ work groups.) In effect, 1188 are available for estimation purposes for two main reasons. First, one period is lost due to the use of lagged values of economic 
variables. (In the main hours' regression - see column (i), Table 1 - the estimated wage is obtained from an equation that includes lagged unemployment.) Second, for each category of worker, some labour markets in some time periods recorded zero returns. Where this occurred in a given market and for a given occupation category, observations for all periods were deleted. There were no returns in the following cases: (fitters, time-rates) North Staffs (1932); (fitters, piece-rates) Burnley (1929, 30, 38), North Staffs (1932, 35), St Helens (all years); (labourers, time-rates) Aberdeen (1927-38); (labourers, piece-rates) Burnley (1929, 30, 32, 38), Dundee (1930, 31, 35-38), Halifax (1928 -30), Liverpool (1929, 31, 33, 35, 37, 38), North Staffs (1929, 31- 33, 36, 37), St Helens (1931, 33), Wigan (1926-36, 38) 


\section{References}

Aldcroft, D.H., 1970, The inter-war economy: Britain, 1919-1939, Batsford, London.

Baland, J-M., J. Drèze, L. Leruth, 1999, Daily wages and piece rates in agrarian economies, Journal of Development Economics 59, 445-461.

Bernanke, B.S., 1986, Employment, hours, and earnings in the Depression: an analysis of eight manufacturing industries, American Economic Review 76, 82-109.

Bernanke, B.S. and J. Powell, 1986, The cyclical behavior of industrial labor markets: a comparison of pre-war and post-war eras, in R. J. Gordon, ed., The American business cycle: continuity and change, Chicago, University of Chicago Press.

Black, A.J., and F.R. FitzRoy, 2000, Earnings curves and wage curves, Scottish Journal of Political Economy 47, 471-486.

Blanchard, O. and L.F. Katz, 1997, What we know and do not know about the natural rate of unemployment, Journal of Economic Perspectives 11, 51-72.

Blanchflower, D.G. and A.J.Oswald, 1994, Estimating the wage curve for Britain, Economic Journal 104, 1025-1043.

Braun, A.R., 1971, Wages in the U.K.: has there been a shift in the Phillips curve?, IMF Staff Papers 18, 136-182.

Card, D., 1995, The wage curve: a review, Journal of Economic Literature 33, 785799.

Card, D. and D. Hyslop, 1996, Does inflation "grease the wheels of the labor market"? NBER Working Paper, No. 5538.

Chapman, A.L., 1952, Wages and salaries in the UK, 1920-38, Cambridge, Cambridge University Press.

Dimsdale, N.H., S.J. Nickell and N. Horsewood, 1989, Real wages and unemployment in Britain during the 1930s, Economic Journal 99, 271-292.

Ehrenberg, R.G., 1971, Fringe benefits and overtime behavior, Massachusetts, Heath.

Feinstein, C.H., 1972, National income, expenditure and output of the United Kingdom 1855-1965, Cambridge, Cambridge University Press.

Garside, W.R., 1990, British unemployment 1919 - 1939, Cambridge, Cambridge University Press.

Hamermesh, D.S, 1993, Labor Demand, Princeton, Princeton University Press. 
Hart, R.A., 1987, Working time and employment, London, Allen and Unwin.

Hart, R.A. and D.I.MacKay, 1975, Engineering earnings in Britain, 1914-68, Journal of the Royal Statistical Society (Series A) 138, 32-50.

Hill, T. P. and K.G.J.C. Knowles, 1956, The variability of engineering earnings, Bulletin of the Oxford University Institute of Statistics 18, 97-139.

Hoel, M. and P. Vale, 1986, Effects on unemployment of reduced working time in an economy where firms set wages, European Economic Review 30, 1097-1104.

Hsiao, C., 1986, Analysis of panel data, Cambridge University Press, Cambridge.

Knowles, K.G.J.C. and D..J. Robertson, 1951a, Earnings in engineering 1926-1948, Bulletin of the Oxford Institute of Statistics 13, 179-200.

Knowles, K.G.J.C. and D.J. Robertson, 1951b, Some notes on engineering earnings, Bulletin of the Oxford Institute of Statistics 13, 223-228.

Knowles, K.G.J.C. and Hill, T. P., 1954, The structure of engineering earnings, Bulletin of the Oxford University Institute of Statistics 16, 272-328.

Lazear, E.P., 1986, Salaries and piece rates, Journal of Business 59, 405-431.

Lipsey, R.G., 1960, the relation between unemployment and the rate of change of money wage rates in the United Kingdom, 1982-1957: a further analysis, Economica 27, 1-31.

Marsh, A., 1965, Industrial relations in engineering, Pergamon Press, London.

Pencavel, J., 1977, Work effort, on-the-job screening, and alternative methods of remuneration, Research in Labor Economics 1, 225-258.

Phillips, A.W., 1958, The relationship between unemployment and the rate of change of money wage rates in the United Kingdom 1861-1957, Economica 25, 285299.

Pollard, S., 1969, The development of the British economy 1914-1967, Edward Arnold, London.

Salop, S.C., 1979, A model of the natural rate of unemployment, American Economic Review 69, 117-125.

Schlicht, E., 1978, Labour turnover, wage structure and natural unemployment, Zeitschrift für die gesamte Staatswissenschaft 134, 337-346.

Seiler, E., 1984, Piece rate vs. time rate: the effect of incentives on earnings, The Review of Economics and Statistics, 66 363-376.

Thomas, B., 1938, The influx of labour into the Midlands 1920-37", Economica n.s. 5, 410-434. 
Von Tunzelmann, G.N., 1982, Structural change and leading sectors in British manufacturing, 1907-68, in Kindelberger, C.P. and di Tella, G. (eds.), Economics in the long view, Volume 3, pp. 1-49, Macmillan, London.

White, H., 1980, A heteroscedasticity-consistent covariance matrix estimator and a direct test for heteroscedasticity, Econometrica 48, 329-347. 